\title{
Dentifrice Containing Extract of Rosmarinus officinalis Linn.: An Antimicrobial Evaluation
}

\begin{abstract}
This study aimed to evaluate the antimicrobial activity of a dentifrice containing an alcoholic extract of rosemary on oral bacteria, compared to a commercially available herbal dentifrice. Standard strains of Streptococcus mutans (ATCC 25175), Streptococcus oralis (ATCC 9811) and Lactobacillus rhamnosus (ATCC 7469) were used, as well as different toothpastes based on rosemary (TR), on propolis (TH), triclosan (positive control) (TPC) and non-fluoridated dentifrice (negative control) (TNC). Bacteria were seeded in Petri dishes and paper discs soaked with dilutions of dentifrice placed on the plates. The inhibition halos were analyzed. It was observed that TR did not show statistical difference in relation to the TH to inhibit $S$. mutans and S. oralis, while TH was more active against L. rhamnosus. The toothpaste containing rosemary extract had the ability to inhibit the growth of S. mutans, S. oralis and L. rhamnosus, revealing an antimicrobial activity similar to commercially available toothpastes for inhibition of S. mutans and S. oralis.
\end{abstract}

${ }^{1}$ Department of Clinical and Preventive Dentistry, UFPE - Universidade Federal de Pernambuco, Recife, PE, Brazil ${ }^{2}$ Department of Toxicology, School of Pharmacy, UFPE

- Universidade Federal de Pernambuco, Recife, PE, Brazil ${ }^{3}$ Department of Biology, Biology School, UFRPE - Universidade Federal Rural de Pernambuco, Recife, PE, Brazil

${ }^{4}$ LIKA - Keizo Asami Laboratory of Immunopathology, UFPE - Universidade Federal de Pernambuco, Recife, PE, Brazil

Correspondence: Prof. Dr. Arnaldo de França Caldas Junior, Av. Prof. Moraes Rego, 1235, 50670-901 Recife, PE, Brasil. Tel: +55-812126-8817. e-mail: arnaldo.caldas@ ufpe.br / caldasjr@alldeia.com.br

Key Words: phytotherapy, dentifrice, Rosmarinus officinalis, antimicrobial activity.

\section{Introduction}

Plants have been always a valuable source of natural products for the maintenance of human health. Indeed, studies on this topic have intensified the last ten years (1). Aromatic and medicinal plants can be used to cure human and other animal diseases, so natural compounds derived from plants should be investigated in order to obtain a better understanding of their properties as well as the safety and efficiency of their clinical use (2). Medicinal plants such as Rosmarinus officinalis (rosemary) (3), Camelia sinensis (green tea), Hipericum perforatum (St. John's wort), Urtica dioica (nettle) (4), Cynara cornigera (wild artichoke) (5), Glycyrrhiza glabra (licorice), Solanum xanthocarpum (yellow-fruit nightshade) and Adhatoda vasica (Malabar nut) (6) have anti-inflammatory, antioxidant and antibacterial properties. In view of such scientific evidence, the exploration of nature should continue, since it may be a source of new active agents for alternative treatment of diseases

Rosmarinus officinalis Linn. (rosemary) is a perennial bush, very common in the Mediterranean region, growing well under different ecological conditions. It is a thick bush with dense foliage and its stem may reach one to two meters high. The leaves are green, sessile, linear, tough, persistent and rugged (7). The essential oil of rosemary has antibacterial, antioxidative and antifungal properties (8). Silva et al. (9) found that the hydroalcoholic extract of Rosmarinus officinalis was effective against oral plankton bacteria (S. mitis, S. sanguinis, S. mutans, S. sobrinus and $L$. casei), involved in the formation of oral biofilm. The scope of phytotherapy using medicinal plants is vast, involving diverse purposes, including use in oral healthcare (10).

Dental caries and periodontal disease are the two most prevalent adverse oral conditions affecting humans worldwide (1). Thus, attention was turned to a condition that requires continuous fight. The prevalent etiological agent of dental caries is the Streptoccocus mutans deposited on dental surface, forming an adherent mass known as dental biofilm or bacterial plaque. S. mutans is an endogenous oral bacterial species, prevailing in the initial stages of caries, whereas Lactobacillus casei, another important microorganism, is encountered during evolution of the cavity (11).

Effective prevention of dental caries and periodontal diseases can be achieved by mechanical removal of dental plaque by proper tooth brushing and flossing. However, most people may not perform sufficiently the mechanical plaque removal (12). Recognizing the limitations of mechanical hygiene methods, a number of studies have been carried out on chemical agents aimed at plaque control $(13,14)$.

The use of a toothbrush with dentifrice is the most widely practiced form of dental hygiene for the control of supragingival plaque. Therefore, toothpaste provides the ideal vehicle for chemical agents. Thus, the association of a toothbrush and dentifrices helps in the removal of plaque and provides application of chemical agents on dental 
surfaces for therapeutic and preventive purposes (13).

Plant extracts incorporated in dentifrice formulas in an attempt to improve antimicrobial activity, have both therapeutic and cosmetic functions. Furthermore, such products are a source of safer or more effective alternatives to synthetically produced antimicrobial agents (15).

In Brazil, there is no commercially available natural rosemary-based toothpaste. In the European countries, however, dentifrices containing rosemary as an aromatic component can be found, but without the definition of rosemary's therapeutic dose, and lacking information concerning other components and/or plant extracts. Therefore, the aim of the present study was to evaluate the antimicrobial activity of a dentifrice containing only an alcoholic rosemary extract with a defined therapeutic dose $\left(\mathrm{LD}_{50}\right)$ on bacteria involved in the etiology of pathological oral processes, compared to commercially available herbal dentifrices.

\section{Material and Methods}

Preparation of Dentifrice

The botanic material (rosemary) was acquired in

Table 1. Determination of MIC $(\mu \mathrm{g} / \mathrm{mL})$ of rosemary extract for $S$. mutans, S. oralis and L. rhamnosus

\begin{tabular}{lccccc}
\hline \multirow{2}{*}{ Bacteria } & \multicolumn{5}{c}{ Concentration of extract $(\mu \mathrm{g} / \mathrm{mL})$} \\
\cline { 2 - 6 } & 20 & 30 & 50 & 100 & 200 \\
\hline S. mutans & + & + & - & - & - \\
S. oralis & + & - & - & - & - \\
L. rhamnosus & + & - & - & - & - \\
\hline
\end{tabular}

(+) growth. (-) absence of growth. a popular market and identified by comparisons with previously deposited material under voucher specimen $n^{\circ} 1641$ in the herbarium of the Instituto de Pesquisas Agricolas de Pernambuco (IPA). After washing and drying at room temperature, the leaves were weighed and macerated in ethanol for 30 days under refrigeration. Subsequently, the extract was filtered and processed with a rotary evaporator at $40{ }^{\circ} \mathrm{C}$ to obtain the dry extract, which was then divided for microbiological, toxicological and phytochemical tests. The extracts were refrigerated between tests.

The minimum inhibitory concentration (MIC) of rosemary extract to be incorporated into the toothpaste was determined using the Macrodilution Method described by Sahm \& Washington II (16) on oral bacteria like S. mutans, L. rhamnosus and $S$. oralis. This technique involves the use of $10 \mathrm{~mL}$ test tubes and a BHI (Brain Heart Infusion - DIFCO ${ }^{\oplus}$, Franklin Lakes, NJ, USA) culture medium, with different concentrations of the bacteria and extract. The rosemary extract demonstrated good inhibition of the bacteria, with a MIC of $30 \mu \mathrm{g} / \mathrm{mL}$ for S. oralis, and $50 \mu \mathrm{g} / \mathrm{mL}$ for both $S$. mutans and L. rhamnosus (Table 1).

The blending of the dentifrice was performed following the specific technology (Table 2) described by Melo et al.(17) and the therapeutic dosage was defined by an effective concentration and $1 / 6$ of lethal dose $\left(\mathrm{LD}_{50}\right)$ of rosemary, according to Sena et al. (3).

The agglutinate/thickener was blended with the humectant and sweetener in distilled water. The solution was vigorously shaken until formation of homogenous mucilage, to which the duly sifted abrasive and foaming agents were added. The quantity of abrasives and other components has shown to be proportionate. The rest of the water was then slowly stirred into the mixture in order to

Table 2. Composition, function and quantity of the formulation of the toothpaste (TP) containing Rosmarinus officinalis Linn. extract (per 100 $\mathrm{g}$ of product)

\begin{tabular}{|c|c|c|c|c|c|c|c|c|c|c|}
\hline Formulations and Ingredients & TP1 & $\mathrm{TP} 2$ & TP3 & TP4 & TP5 & TP6 & TP7 & TP8 & TP9 & TP 10 \\
\hline Calcium carbonate (abrasive) & 35.0 & 35.0 & 40.0 & 40.0 & 40.0 & 45.0 & 45.0 & 45.0 & 50.0 & 40.0 \\
\hline Sorbitol (humectant) & 15.0 & 20.0 & 20.0 & 5.0 & 25.0 & 30.0 & 35.0 & 40.0 & 40.0 & 20.0 \\
\hline $\begin{array}{l}\text { Carboxymethylcellulose } \\
\text { (agglutinant/thickener) }\end{array}$ & 0.7 & 0.7 & 0.7 & 0.7 & 0.7 & 0.5 & 0.5 & 0.5 & 0.5 & 0.5 \\
\hline Carbopol 940 (agglutinant/thickener) & 0.3 & 0.3 & 0.3 & 0.3 & 0.3 & 0.5 & 0.5 & 0.5 & 0.5 & 0.5 \\
\hline Sodium laurylsulfate (foaming agent) & 1.0 & 1.5 & 2.0 & 2.0 & 2.5 & 3.0 & 3.5 & 3.5 & 4.0 & 4.0 \\
\hline Saccharin (sweetener) & 0.5 & 0.6 & 0.7 & 0.8 & 0.9 & 1.0 & 1.5 & 1.5 & 1.5 & 1.0 \\
\hline Sodium benzoate (conservative) & 0.1 & 0.1 & 0.1 & 0.2 & 0.2 & 0.2 & 0.2 & 0.2 & 0.1 & 0.1 \\
\hline Menthol (flavoring) & 1.0 & 1.0 & 1.0 & 1.0 & 1.0 & 1.0 & 1.0 & 1.0 & 1.0 & 1.0 \\
\hline Vegetal extract (antimicrobial agent) & 9.53 & 9.53 & 9.53 & 9.53 & 9.53 & 9.53 & 9.53 & 9.53 & 9.53 & 9.53 \\
\hline Distilled $\mathrm{H}_{2} \mathrm{O}$ (diluent) & 100 & 100 & 100 & 100 & 100 & 100 & 100 & 100 & 100 & 100 \\
\hline
\end{tabular}


avoid the formation of foam. After obtaining a homogenous paste, the extract was added and then vigorously shaken until obtaining the consistency of a soft, shiny cream. The toothpaste, which had a greenish-brown coloration, was quickly packaged in order to avoid its drying out. Different formulations were tested with varied concentrations of the components in search the ideal consistency of toothpaste (17). No fluoride was added to the dentifrice to keep the test agent as isolated as possible, as recommended in the pre-clinical tests. The $\mathrm{pH}$ of the dentifrice was measured using the appropriate electrode (Phmetro DM-22 ${ }^{\oplus}$, Digimed, São Paulo, SP, Brazil). Characteristics such as the color, odor and appearance were visually analyzed based on comparisons with the reference sample. Density was determined using a metallic pycnometer with a lid (ASTM D1475 ; São Paulo, SP, Brazil).

\section{Bacterial Strains}

Standard strains of Streptococcus mutans (ATCC 25175), Streptococcus oralis (ATCC 9811) and Lactobacillus rhamnosus (ATCC 7469) were obtained from the Reference Material Laboratory of the Brazilian National Institute for Quality of Health Control of the Oswaldo Cruz Foundation (Rio de Janeiro, RJ, Brazil). The strains were reactivated at the Culture Collection Laboratory of the Department of Antibiotics of the Universidade Federal de Pernambuco (Recife, PE, Brazil).

\section{Selection of Dentifrices}

The following dentifrices were tested:

Toothpaste A (TR): Test (dentifrice containing rosemary extract); Toothpaste B (TH): Herbal dentifrice (containing mauve, cinnamon, peppermint and propolis - Sorriso Herbal com Própolis ${ }^{\oplus}$, Colgate-Palmolive, Rio Claro, SP, Brazil); Toothpaste (TPC): dentifrice positive control (containing triclosan - Colgate Total $12^{\circledR}$, Colgate-Palmolive, São Paulo, SP, Brazil); Toothpaste (TNC): dentifrice without fluoride (negative control) - (Philips ${ }^{\oplus}$; Glaxo Smithkline, Rio de Janeiro, RJ, Brazil)

\section{Antimicrobial Test of Dentifrices}

For solubility tests of antimicrobial dentifrice components, $10 \mathrm{~g}$ of each dentifrice were weighed and diluted in $10 \mathrm{~mL}$ of ethanol (1:1), according to the methodology employed by Liza Barreto et al. (18). The mixtures were agitated in a vortex ${ }^{\circledast}$ (Vortex Genie 2, Bohemia, NY, USA) for $3 \mathrm{~min}$ in order to obtain a homogenous solution, centrifuged (Xiangzhi Centrifuge ${ }^{\oplus}$ TGL 16 MB, Changsha Xiangzhi, Hunan, China) for $10 \mathrm{~min}$ at $1000 \mathrm{rpm}$ in order to precipitate the solid particles of the dentifrice. The supernatant contained the main active components of the dentifrices (separated by centrifugation). The resulting supernatants were diluted in the following proportions: 1:2, 1:4 and 1:8.

Standardized Single Disk Method was employed (19) for the determination of rosemary dentifrice's antimicrobial activity on standard strains of S. mutans, $S$. oralis and $L$. rhamnosus. Sterile Petri dishes containing $10 \mathrm{~mL}$ of BHI medium (Brain Heart Infusion - DIFCO ${ }^{\circledR}$; DIFCO, Franklin Lakes, NJ, USA) were inoculated with suspensions of $S$. mutans, S. oralis and L. rhamnosus. Sterile paper disks were soaked with $60 \mu \mathrm{L}$ of each diluted supernatant solution and placed on the dishes, arranged in a way to avoid the overlapping of inhibition halos. The positive and negative controls underwent the same procedures. Simultaneously, a disc soaked in pure ethanol was used. The duly labeled dishes were placed in incubator for $48 \mathrm{~h}$ at $37^{\circ} \mathrm{C}$. S. mutans was placed under microaerophilic conditions, whereas the other bacteria were placed under conditions of aerobiosis. Tests were performed in triplicate for each culture in order to reduce variability, control the study and obtain reliable results.

The data are expressed as means and standard deviations. The dentifrices were pairwise compared in two conditions: controlling the type of bacteria and controlling the type and dilution of bacteria. Two-way ANOVA with Tukey post-tests were used to compare the mean diameters of the inhibition halos. The level of significance was set at $p \leq 0.05$. Statistical analysis was performed using the SPSS 20.0 software program.

\section{Results}

The final dentifrice product exhibited a 6.0 to $6.5 \mathrm{pH}$ in the different prepared formulations. The appearance was similar to the reference sample, with no visible separation of phases, precipitation, turbidity or lack of shine. The color, odor and density were normal and in line with

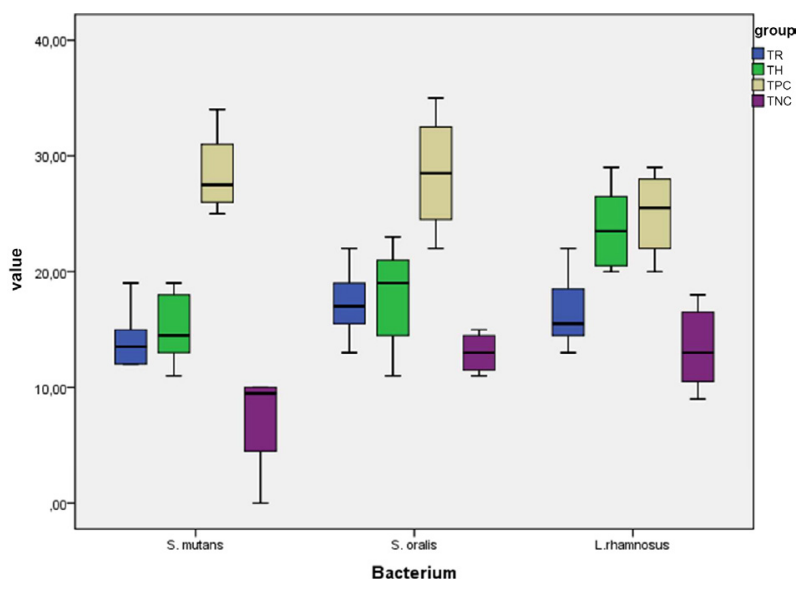

Figure 1. Boxplot comparison of mean inhibition halos ( $\mathrm{mm})$ between $\mathrm{TR}, \mathrm{TH}, \mathrm{TPC}$ and TNC controlling the type of bacterium. 
standard values.

Figure 1 displays the results of TR in vitro antimicrobial activity on S. mutans, S. oralis and L. rhamnosus, as well as comparisons with TH, TPC and TNC.

Regarding S. mutans, there was no statistically significant difference when comparing TR with $\mathrm{TH}$ $(p=0.914)$, thereby demonstrating similar antimicrobial activity among the toothpastes. A significant difference was found in the comparison of TR with $\operatorname{TNC}(p=0.003)$ and TR with TPC $(p=0.000)$.

In the case of $S$. oralis, no statistically significant difference was found in the comparison between TR and TH ( $p=0.987)$ or TNC $(p=0.063)$, which demonstrated similar antimicrobial activity. However, significant differences were detected when comparing TR with TPC $(p<0.001)$; TPC demonstrated greater antimicrobial activity than TR.

Regarding L. rhamnosus, a significant difference was found in the comparison between TR and TH $(p=0.001)$ and with TR and TPC $(p<0.001)$, demonstrating greater antimicrobial activity for TH and TPC. However, no statistically significant difference was found when comparing TR with TNC ( $p=0.284)$.

There was no statistically significant difference between TR and TH when comparing the different dilutions and pathogens used, except with regard to L. rhamnosus, for which $\mathrm{TH}$ has proved to be more active at all tested dilutions.

\section{Discussion}

Dentifrice is a general term employed to describe preparations used with a toothbrush for the purposes of cleaning and polishing the teeth and it can be prepared as powder, gel or toothpaste, depending on the water content (20). Dentifrices containing plant extracts have been investigated and administered for a number of years in different countries $(1,21)$. Although previous studies have already addressed the antimicrobial activity of rosemary on S. mutans, creation of a toothpaste with a defined therapeutic dose of rosemary (as the only antimicrobial agent in the formula) is a novelty. The novelty is in the product. In Europe, one can find dentifrices with the essential oils of rosemary used as flavoring, but not as a therapeutic dose.

Along this line of reasoning, Liza Barreto et al. (18) analyzed in vitro the antimicrobial potential of seven dentifrices containing medicinal herbs and concluded that most of the dentifrices exhibited antimicrobial activity against the analyzed microorganisms. In a similar study involving only a clinical extrapolation, Amoian et al. (15) also produced and evaluated a toothpaste containing a botanical extract of Calendula officinalis.

In this study, based on the contribution of these theorists, a dentifrice was made with the alcoholic extract of Rosmarinus officinalis Linn. and evaluated for its antimicrobial potential. In an in vitro study evaluating the antimicrobial potential of 14 commercially available herbal dentifrices against $S$. mutans, Lee et al. (22) found that the antimicrobial power varied greatly among toothpastes. The present findings demonstrated that the dentifrice containing rosemary extract exhibited an inhibiting capacity for the bacterial growth of S. mutans, S. oralis and L. rhamnosus, showing similar antimicrobial potential to the commercial toothpaste "Sorriso Herbal com Própolis ${ }^{\circledast "(C o l g a t e-P a l m o l i v e) ~ f o r ~ t h e ~ i n h i b i t i o n ~ o f ~} S$. mutans and S. oralis. The effect of herbal dentifrice consists in the combination of herbs and propolis. The dentifrice contains malva, cinnamon, mint and propolis, all of which exhibit medicinal properties.

Komiyama et al. (23) carried out an in vitro assessment of the effect of commercially available dentifrices in Brazil in the context of S. mutans growth, using a methodology similar to the present study. Those authors concluded that dentifrices containing triclosan or a combination of herbal extracts were the most effective for inhibiting the growth of this bacterium. Jenner et al. (1) found that the growth of $S$. mutans was also inhibited by the action of five herbal toothpastes: (Colgate Herbal ${ }^{\oplus}$-Colgate-Palmolive, São Paulo, SP, Brazil), Babool ${ }^{\circledR}$ (Dabur, Kaushambi, New Delhi, India), Meswak ${ }^{\oplus}$-Dabur), Neem Active ${ }^{\circledast}$ (Sattiva Cosméticos, Aparecida de Goiânia, G0, Brazil) and Dabur $\mathrm{RED}^{\odot}$ (Dabur), leading the authors to suggest in vivo studies on the subject. Gupta et al. (24) evaluated the anti-plaque efficacy of a commercially available herbal dentifrice compared to conventional fluoride toothpaste and found a significant reduction in mean plaque index scores in subjects of both groups. In the present study, besides the inhibition of S. mutans, the S. oralis and L. rhamnosus microorganisms were also inhibited, suggesting that the efficacy of this dentifrice is greater than the previously analyzed dentifrices. Moreover, the dentifrice containing rosemary extract was compared with a commercial brand containing propolis and the findings demonstrated similar antimicrobial activity between the two dentifrices with regard to S. mutans and S. oralis. However, this did not occur with L. rhamnosus, the propolis-based dentifrice being significantly more effective than the dentifrice containing rosemary. The choice of propolis as basis for comparison of the dentifrices was due to an earlier study in the literature (25).

In the present study, the best results with the dentifrice containing the alcoholic extract of rosemary occurred for the pathogens S. mutans and S.oralis, for which antimicrobial activity of the rosemary-based dentifrice proved similar to the commercial dentifrice "Sorriso Herbal com Própolis". Producing oral hygiene products with 
natural ingredients is a viable alternative for the control of bacterial plaque and caries as well as promotes the use of benefits provided by nature and available within the habitat. Furthermore, according to Liza-Barreto et al. (2005) (18), plant extracts incorporated into dentifrice formulae add to the action of fluorine, thereby improving (and increasing) the therapeutic properties of the product.

The present study demonstrated that a dentifrice containing exclusively rosemary extract has the capability of inhibiting the growth of the studied bacteria. However, for the inhibition of L. rhamnosus, a propolis-based commercial dentifrice was more effective than the dentifrice containing rosemary extract.

\section{Resumo}

0 estudo teve como objetivo avaliar a atividade antimicrobiana de um dentifrício extrato alcoólico de alecrim sobre bactérias orais, comparando-o a um dentifrício herbal disponivel no mercado. Cepas padrão de Streptococcus mutans (ATCC 25175), Streptococcus oralis (ATCC 9811) e Lactobacillus rhamnosus (ATCC 7469) foram utilizadas, bem como diferentes dentifrícios à base de alecrim (TR), própolis (TH), triclosan (controle positivo) (TPC) e sem flúor (controle negativo) (TNC). Placas de Petri foram inoculadas com as bactérias e discos de papel embebidos com diluições de cada dentifrício foram colocados nas placas. Em seguida, foram analisados os halos de inibição. Observou-se que o TR não mostrou diferença estatística em relação ao TH para inibição dos $S$. mutans e $S$. oralis, enquanto $\mathrm{TH}$ foi mais ativo contra L. rhamnosus. 0 dentifrício contendo extrato de alecrim foi capaz de inibir o crescimento de $S$. mutans, S. oralis e L. rhamnosus, revelando uma atividade antimicrobiana semelhante ao dentifricio disponivel comercialmente na inibição de $S$. mutans e S. oralis.

\section{References}

1. Jenner $F$, Jaleel VA, Kulshrestha R, Maheswar G, Rao PK, Kranthi J. Evaluating the antimicrobial activity of commercially available herbal toothpastes on microorganisms associated with diabetes mellitus. J Contempor Dent Pract 2013;14:924-929.

2. Hotwani K, Baliga S, Sharma K. Phytodentistry: use of medicinal plants. J Complement Integr Med 2014;11:233-251.

3. Sena KXFR, Andrade MSAS, Lima RC, Santos ER. Atividades biológicas do Rosmarinus officinalis L. Bol Soc Brot Ser 1993;2:97-109.

4. Bitiren M, Musa D, Ozgonul A, Ozaslan M, Kocyigit A. Protective effects of green tea (Camelia sinensis), Hypericum perforatum and Urtica dioica on hepatic injury and lymphocyte DNA damage induced by carbon tetrachloride in Wistar rats. Int. J. Pharmacol 2010;6:241-248.

5. Ahmida M. Antidiabetic, antihyperlipedemic and antioxidant effects of aqueous extract of the root of Cynara cornigera in alloxan-induced experimental diabetes mellitus. Int J Pharmacol 2011;7:782-789.

6. Manek RA, Sheth NR, Vaghasiya JD, Malaviya SV, Jivani NP, Chavda JR. Study of herb-herb interaction potential of Glycyrrhiza glabra with Solanum xanthocarpum and Adhatoda vasica on mast cell stabilizing activity. Int J Pharmacol 2011;7:589-598.

7. Begum A, Sandhya S, Ali SS, Vinod KR, Reddy S, Banji D. An in-depth review on the medicinal flora Rosmarinus officinalis (Lamiaceae). Acta Sci Pol Technol Aliment 2013;12:61-73.
8. Kazemi $M$, Rostami $H$, Ameri A. The study of compositions and antimicrobial properties of essential oil of Origanum vulgare and Rosmarinus officinalis on human pathogens. Curr Res Bacteriol 2012;5:1-12

9. Silva MSA, Silva MAR, Higino JS, Pereira MSV, Carvalho AAT. Atividade antimicrobiana e antiaderente in vitro do extrato de Rosmarinus officinalis Linn. sobre bactérias orais planctônicas. Rev Bras Farmacogn 2008;18:236-240.

10. Mohire NC, Yadav AV. Chitosan-based polyherbal toothpaste: A novel hygiene product. Ind J Dent Res 2010;21:380-384

11. Buischi YP. Promotion of oral health in the dental clinic. São Paulo: Artes Médicas, 2000.

12. Pradeep AR, Agarwal E, Naik SB. Clinical and microbiologic effects of commercially available dentifrice containing Aloe vera: a randomized controlled clinical trial. J Periodontol 2012;83:797-804.

13. Tatikonda A, Debnath $S$, Chauhan V, Chaurasia V, Taranath $M$, Sharma A. Effects of herbal and non-herbal toothpastes on plaque and gingivitis: a clinical comparative study. J Int Soc Prev Community Dent 2014;4:126-129.

14. Hebbal M, Ankola AV, Sharma R, Johri S. Effectiveness of herbal and fluoridated toothpaste on plaque and gingival scores among residents of a working women's hostel - a randomized controlled trial. Oral Health Prev Dent 2012;10:389-395.

15. Amoian B, Moghadamnia AA, Mazandarani M, Amoian MM, Mehrmanesh $S$. The effects of calendula extract toothpaste on the plaque index and bleeding in gingivitis. Res J of Medicinal Plant 2010;4:132-140.

16. Sahm DF, Washington II JA. Antibacterial susceptibility tests: Dilution methods. In: Balows A, Hauser WJ, Hermann KL, Isenberg HD, Shamody HJ. Manual of clinical microbiology. 5ed. Washington: American Society for Microbiology; 1991. p. 1105-1116.

17. Melo AFM, Albuquerque MM, Higino JS, Silva MAL, Santos EM, Marques GS, et al.. Desenvolvimento de dentifrício com o extrato bruto seco da casca do caule de Anacardium occidentale Linn. BIO FARMA-Rev Téc Cient Farm Bioquím Anál Clín Toxicol 2006;1:101-105.

18. Liza Barreto V, Feitosa AMSC, Araújo TJ, Chagas FK, Costa LK. Acción antimicrobiana in vitro de dentifrices contiendo fitoterápicos. Av Odontoestomatol 2005;21:195-201.

19. Bauer AW, Kirby WMM, Sherris JC, Turc M. Antibiotic susceptibility test by a standardized single disk method. Am J Clin Pathol 1966;45:493496.

20. Sanz M, Serrano J, Iniesta M, Santa Cruz I, Herrera D. Antiplaque and antigingivits toothpastes. Monogr Oral Sci 2013;23:27-44.

21. Verkaik MJ, Busscher HJ, Jager D, Slomp AM, Abbas F, Van der Mei HC. Efficacy of natural antimicrobials in toothpaste formulations against oral biofilms in vitro. J Dent 2011;39:218-224.

22. Lee SS, Zhang WU, Yiming LI. The antimicrobial potential of 14 natural herbal dentifrices-Results of an in vitro study. JADA 2004;135:11331141

23. Komiyama EY, Martins CAP, Jorge AOC, Koga-Ito CY. In vitro study of commercially available toothpastes in Brazil: inhibitory effect on Streptococcus mutans. Rev Odontol UNICID 2004;16:21-27.

24. Gupta P, Agarwal N, Anup N, Manujunath BC, Bhalla A. Evaluating the anti-plaque efficacy of meswak (Salvadora persica) containing dentifrice: a triple blind controlled trial. J Pharm Bioallied Sci 2012;4:282-285.

25. Bhat N, Bapat S, Asawak K, Tak M, Chaturvedi P, Gupta W, et al.. The antiplaque efficacy of propolis-based herbal toothpaste: a crossover clinical study. J of Nat Sci Biol and Med 2015;6:364-368.

Received May 28, 2016 Accepted July 1, 2016 